\title{
1192U90 in Animal Tests That Predict Antipsychotic Efficacy, Anxiolysis, and Extrapyramidal Side Effects
}

Greg C. Rigdon, Ph.D., Mark H. Norman, Ph.D., Barrett R. Cooper, Ph.D., James L. Howard, Ph.D., Virginia M. Boncek, Walter L. Faison, B.A., Kevin P. Nanry, B.S., and Gerald T. Pollard, Ph.D.

1192490 aras developed on the assumption that antagonism of 5-HT2 receptors efficacy yields more potently than $\mathrm{D}_{2}$ receptors against positive and negatioe symptoms of schizophrenia with minimal liability for extrapyramidal side effects (EPSs), and that 5-HT A agonism further reduces EPS and provides anxiolytic and antidepressant activity. 1192490 was submitted to four tests that predict antipsychotic efficacy (antagonism of apomorphine-induced climbing in mouse, antagonism of apomorphine-induced circling in rats with unilateral 6-OHDA lesions, antagonism of amphetamine-indaced hyperlocomotion in rat, and inhibition of conditioned acoidance in rat), tavo tests of 5-HT2 function (antagonism of 5-MeODMT-induced head twitches in mouse and antagonism of 5-HTP-induced wet dog shakes in rat), and three tests that predict EPS liability (antagonism of apomorphine-induced stereotypy in monse and rat and induction of catalepsy in mouse). ED 5 as (mg/kg PO) arere as follow's: climbing 10.1, circling 7.9, hyperlocomotion 6.6 , and arodance 5.7 ; heat taitches 5

KEY WORDS: Schizophrenia; Dopamine; Serotonin;

Clozapine; Risperidone; Haloueridol: 1192490

Schizophrenia is a chronic syndrome characterized by positive psychotic symptoms (delusions, hallucinations, thought disorder) and negntie' symptoms (social isola-

From the Pharmacology and Molecular Therapeutics Division and Medicinal Chemistry Division (MHN), Claxo Welloome, Inc., Research Triangle Park, NC.

Address correspondence to: Greg C. Rigdon, Ph.D., CNS Clinical Research, (ilaxo Welloome, Inc., Re'search Triangle l'ark, NC 27709.

Received June 30, 1995; revised October 5. 1995; accepted October 25,1995 and wet dog shakes 4.6; stereotypy in mouse 91.1, stereotypy in rat 133.4, and catalepsy 192.4. The ratio of $E D_{50}$ for stereotypy antagonism to $E D_{50}$ for climbing antagonism was 9 (compared to 4, 3, and 4 for clozapine, risperidone, and haloperidol). The ratio of $E D_{50}$ for catalepsy induction to $E D_{50}$ for climbing antagonism was 19 compared to 7, 2, and 17 for clozapine, risperidone, and haloperidol). 1192490 ans also submitted to three tests that predict anxiolysis: It produced only a small increase in punished leoer pressing for food in rat (Geller-Seifter conflict test), which is specific for rapid-onset efficacy, but produced large increases in punished key pecking for food in pigeon and cork gnawing in rat, which identify the delayed onset 5-HT in agonists such as buspirone. The results suggest that 1192490 would be effective for positive and negation symptoms of schizophrenin, with minimal liability for EPSs, and may also have' anxiolytic properties.

[Neuropsychopharmacology 15:231-242, 1996]

tion, blunted affect, poverty of speech, marked lack of initiative) (Andreasen 1985). All antipsychotics antagonize dopamine (DA) $D_{2}$ receptors, and DA agonists can induce schizophrenic symptoms in remitted patients and normals (Carlsson 1988). However, no consistent alterations in DA function have been demonstrated in unmedicated schizophrenics.

"Typical" antipsychotics such as haloperidol relieve primarily positive symptoms and produce extrapyramidal side effects (EPSs) at or near therapeutic doses. Clozapine is classified as "atypical" because it is effective against positive and negative symptoms without 
Figure 1. 1192U90, 2-amino-N(4-(4-(1,2-benzisothiazol-3-v)1-piperazinyl)butyl)benzamide hydrochloride.

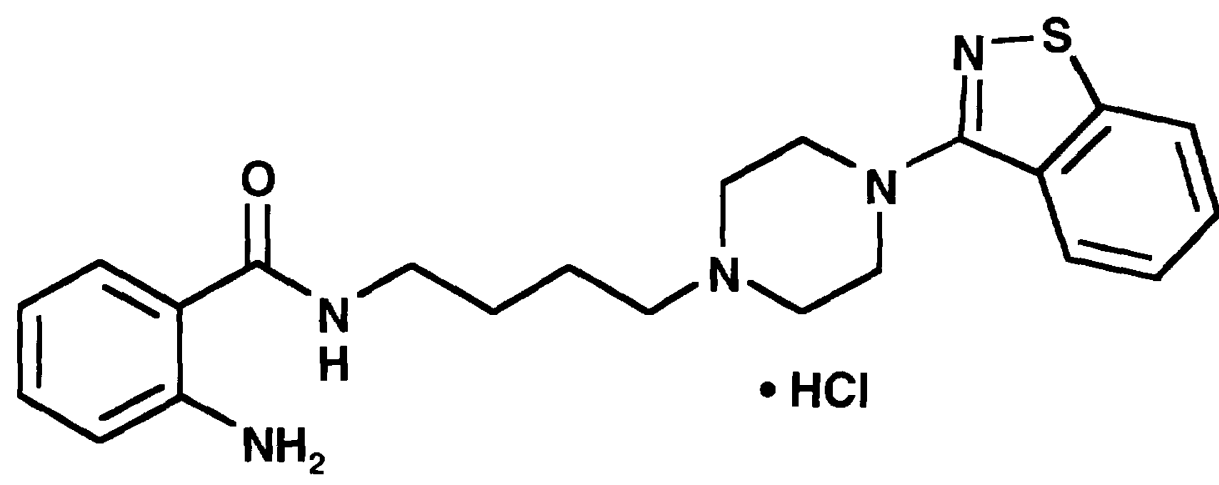

causing EPSs and is effective in patients resistant to treatment with typical antipsychotics (Jann 1991; Meltzer et al. 1989). Clozapine's unusual clinical profile may result from the combination of potent serotonin $2\left(5-\mathrm{HT}_{2}\right)$ antagonism with moderate $\mathrm{D}_{2}$ antagonism (Meltzer et al. 1989). Concurrent treatment with a selective 5- $\mathrm{HT}_{2}$ antagonist reduces the EPSs induced by haloperidol (Bersani et al. 1986). Another theory is that clozapine's $\alpha$-adrenergic antagonism reduces the EPSs induced by typical antipsychotics (Baldessarini et al. 1992). Unfortunately, clozapine induces agranulocytosis in about $1 \%$ of patients and seizures in up to $5 \%$ (Sandoz Pharmaceuticals 1994). A drug with an atypical profile without clozapine's limiting side effects would represent an important advance.

1192U90, 2-amino-N-(4-(4-(1,2-benzisothiazol-3-yl)-1-piperazinyl)butyl)benzamide hydrochloride (Figure 1), synthesized by Mark Norman and Frank Navas at Burroughs Wellcome Co., is a potential atypical antipsychotic (Norman et al. in press). It was developed on the assumptions that reduced EPS liability may be combined with efficacy for positive and negative symptoms of schizophrenia by antagonizing $5-\mathrm{HT}_{2}$ receptors more potently than $\mathrm{D}_{2}$ receptors (Altar et al. 1986; Meltzer et al. 1989) and that the combination of $5-\mathrm{HT}_{1 \mathrm{~A}}$ agonism with $D_{2}$ antagonism is beneficial for the treatment of schizophrenia (Goff et al. 1991). 1192490 binds to these receptors with the following relative affinities $\left(\mathrm{K}_{\mathrm{i}} \mathrm{nM}\right)$ : $5-\mathrm{HT}_{2}(1.5)>5-\mathrm{HT}_{1 \mathrm{~A}}(2.5)>\mathrm{D}_{2}(22)$. It also binds potently to adrenergic $\alpha_{1}$ receptors (0.3) (Jones-Humble et al. 1996). 1192U90's chemical structure is different from clozapine's and therefore may not induce agranulocytosis. There has been no evidence of seizures in animals at up to 20 times 1192U90's predicted therapeutic doses in dog and rat (data on file at Glaxo Wellcome, Inc.).

1192 U90 was submitted to behavioral tests that predict antipsychotic efficacy and EPS potential. Tests to predict efficacy were antagonism of apomorphine-induced climbing in mouse and antagonism of amphetamine-induced locomotion in rat, which reflect antagonism of limbic system DA receptors (Kelly et al. 1975; Costall et al. 1979, 1981); antagonism of apomorphine- induced circling in rats with unilateral 6-hydroxydopamine (6-OHDA) lesions of striatum, which reflects antagonism of supersensitive DA receptors (Ungerstedt et al. 1974); and inhibition of conditioned avoidance responding in rat (Ögren and Archer 1994). Antagonism of head twitches in mouse and wet dog shakes in rat induced by 5 -HT agonists was used to determine in vivo 5- $\mathrm{HT}_{2}$ antagonism (Colpaert and Janssen 1983; Goodwin and Green 1985). EPS liability was assessed by antagonism of apomorphine-induced stereotypy in mouse and rat (Worms and Lloyd 1979) and by induction of catalepsy in mouse (Worms and Lloyd 1979). The reference antipsychotics tested were haloperidol, which readily induces EPSs in humans (Schwartz and Brotman 1992); clozapine, which has a very low liability for EPSs (Schwartz and Brotman 1992); and risperidone, a new drug with an EPS liability less than haloperidol's but greater than clozapine's (Meltzer 1993).

Because stress and anxiety are often associated with schizophrenic episodes (Liberman and Corrigan 1992), 1192 U90 was also submitted to tests that predict anxiolytic efficacy. Rapid-onset anxiolytics such as benzodiazepine full agonists and other sedative-hypnotics, which have some clinical effect within minutes or hours of administration (Baldessarini 1985), produce large increases in punished behavior in several species (reviewed in Pollard and Howard 1990). Delayed-onset anxiolytics such as the $5-\mathrm{HT}_{1 \mathrm{~A}}$ agonist azapirones (Goa and Ward 1986; Lader 1988; Borison et al. 1990) and the tricyclic antidepressants, which have a therapeutic effect only after weeks of treatment, produce only small or inconsistent increases in punished behavior in mammals when injected acutely (Pollard and Howard 1990; Howard and Pollard 1990; Pollard et al. 1992). The azapirones (buspirone, gepirone, ipsapirone, tandospirone) do, however, produce large increases in punished key pecking in pigeon (Nanry et al. 1991; Pollard et al. 1992; Brocco et al. 1990; Mansbach et al. 1988). Typical antipsychotics generally do not increase punished behavior. In our hands, chlorpromazine had no effect on punished key pecking in pigeon (Nanry et al. 1991) or punished lever pressing in rat (Pollard and Howard 1979), 
nor did haloperidol in another study with these species (Wiley et al. 1993). These and other typical antipsychotics are not generally considered anxiolytic. The atypical antipsychotic risperidone did not increase punished behavior either (Moore et al. 1994). However, the atypical antipsychotic clozapine and its congener olanzapine have repeatedly produced moderate increases in punished behavior in mammals (Wiley et al. 1993; Moore et al. 1994; Nanry et al. 1995). Clozapine was reported to decrease the level of anxiety and aggressive behavior in schizophrenics (Rimon et al. 1994). 1192U90 was assessed for antipunishment activity in rat to determine whether it was benzodiazepinelike and in pigeon to determine whether it was azapironelike. In the rat test (modified Geller-Seifter conflict), a maximally effective dose of chlordiazepoxide was run as a standard, and risperidone and clozapine were tested for comparison. In the pigeon test, a maximally effective dose of buspirone was tested as a standard, and risperidone and clozapine were tested for comparison.

A rat given access to a cork for 30 minutes a day will gnaw away an amount that reaches an asymptote of about 0.03 to $0.05 \mathrm{~g}$ after several months (Pollard and Howard 1991). Sedative-hypnotic anxiolytics increase the amount to a maximum of about $0.15 \mathrm{~g}$, and $5-\mathrm{HT}_{1 \mathrm{~A}}$ anxiolytics, injected acutely, typically increase the amount to 0.25 to $0.3 \mathrm{~g}$. Of approximately 30 standard compounds tested, the $5-\mathrm{HT}_{1 \mathrm{~A}}$ ligands buspirone, gepirone, ipsapirone, and tandospirone are virtually unique in the magnitude of median increase and the presence of very high values in some subjects (Pollard and Howard 1991; Pollard et al. 1992). 1192U90 was assessed for azapironelike activity in this test also.

\section{METHODS}

\section{Subjects}

For all experiments except conditioned avoidance and the anxiolytic tests, male CD-1 mice weighing 20 to $25 \mathrm{~g}$ or Wistar rats weighing 200 to $300 \mathrm{~g}$ were obtained from Charles River Laboratories (Raleigh, NC) and housed in group cages on a 12-hour light--dark cycle (light on 0600 to 1800) with free access to food and water. For condjtioned avoidance, Geller-Seifter conflict, and cork gnawing, ovariectomized Long-Evans rats from Charles River Laboratories were maintained in the same way as the Wistars except for being on a reverse light-dark cycle (light on 1600 to 0400). Adult male white Carneaux pigeons from Palmetto Pigeon Plant (Sumter, SC) were housed in individual cages in a vivarium with controlled temperature $\left(22 \pm 2^{\circ} \mathrm{C}\right)$ and humidity $(50 \% \pm$ $10 \%$ ) on a 12-hour light-dark cycle (light on 0600 to 1800) with water and grit available ad libitum. All subjects were well trained on their respective tasks, with stable baseline behavior from day to day, and had pre- viously performed the task under the influence of other compounds.

The procedures followed U.S. Public Health Service guidelines for the care and use of laboratory animals.

\section{General Procedure}

Test compounds were suspended in $0.5 \%$ methylcellulose vehicle and injected in a volume of $1 \mathrm{ml} / \mathrm{kg}$ except as noted. $\mathrm{ED}_{50 \mathrm{~S}}$ (doses required for $50 \%$ of maximal response) were calculated on percent antagonism or percent inhibition by the method of Litchfield and Wilcoxon (Pharm/PCS Software, Philadelphia, PA) except as noted.

\section{Tests That Predict Antipsychotic Efficacy}

Antagonism of Apomorphine-Induced Climbing in Mouse. Mice were acclimated to round, wire mesh cages for at least 30 minutes prior to testing. Test compound or vehicle was injected PO 60 minutes before apomorphine ( $5 \mathrm{mg} / \mathrm{kg} \mathrm{SC}, N=6$ per dose). Subjects were scored 5 minutes after apomorphine administration and at 5minute intervals for 30 minutes for climbing as follows: 4 feet on cage floor, $0 ; 1$ to 3 feet on cage wall, 1; all 4 feet off cage floor, 2. Scores for the six observation periods were averaged for each subject and group averages were calculated. Percent antagonism was determined by comparing scores of subjects treated with test compound to the scores of subjects treated with vehicle in the same experiment.

Antagonism of Apomorphine-Induced Circling in Rats with Unilateral Striatal Lesions. Stereotaxic surgery was performed under halothane anesthesia. The skull was exposed, a burr hole was drilled, and $8 \mu \mathrm{g}$ of 6-OHDA dissolved in $4 \mu \mathrm{l}$ of saline containing $0.2 \%$ ascorbate was infused over 2 minutes into the left caudate putamen (stereotaxic coordinates from bregma and top of skull were -0.92 anterior, 3.8 lateral, 5.0 vertical (Paxinos and Watson 1986). After 2 weeks of recovery, each subject was placed in a harness and tethered in a round chamber (Coulbourn Instruments, Lehigh Valley, PA) for a 30-minute acclimation period. Then apomorphine $(0.6 \mathrm{mg} / \mathrm{kg} \mathrm{SC})$ was injected, and the subject was replaced in the chamber. Rotations contralateral to the lesioned side were counted for 60 minutes. One week later, the test compound was injected PO 1 hour before apomorphine $(0.6 \mathrm{mg} / \mathrm{kg} \mathrm{SC})$, and contralateral rotations were counted for 60 minutes. The difference in number of rotations between test compound + apomorphine and apomorphine alone was calculated for each rat (within-subject design).

Antagonism of Amphetamine-Induced Hyperlocomotion in Rat. Activity was measured in 12 Plexiglas chambers ( $42 \mathrm{~cm}$ square, $23 \mathrm{~cm}$ high) in photo-beam devices that measured horizontal movement (Opto-Varimex Minor S, Columbus Instruments, Columbus, $\mathrm{OH}$ ). 
1192U90, clozapine, or vehicle was injected PO. 1 hour later, $\mathrm{d}$-amphetamine $(1 \mathrm{mg} / \mathrm{kg})$ or its vehicle (distilled water) was injected SC, the subjects were placed in the chambers, and activity was recorded at 2-minute intervals for 60 minutes. Treatment conditions were randomized for each run of 12 subjects ( $N=7$ to 24 per condition). Differences between treatments were evaluated by analysis of variance (ANOVA) followed by Dunnett's test (Instat, GraphPad Software, San Diego, CA).

Conditioned Avoidance Response in Rat. Subjects were given daily 100-trial avoidance sessions (about $40 \mathrm{~min}$ utes) 4 days a week, with Mondays and Thursdays as control days and Tuesdays and Fridays as drug test days. The task was to respond to a tone and light cue within 5 sec by crossing from one half of the computer-controlled shuttle box (Lehigh Valley Electronics, Lehigh Valley, PA) to the other half to avoid foot shock. If the subject did not cross within $5 \mathrm{sec}$, the grid floor was electrified (five 250-msec 0.3-mA pulses separated by 750 -msec intervals); the rat could then escape the shock by crossing. The intertrial interval was $20 \mathrm{sec}$. Measures of interest were avoids, omits (escape failures), and intertrial crosses. These values were submitted to repeated-measures ANOVA, with post hoc comparisons by Dunnett's test; where data failed the test of normality or equal variance, the analysis was done on ranks (SigmaStat, Jandel Scientific, San Rafael, CA).

\section{Tests That Predict 5- $\mathrm{HT}_{2}$ Receptor Antagonism}

Antagonism of 5-MeODMT-Induced Head Twitches in Monse. In previous studies (data on file at Glaxo Wellcome, Inc.), 5-MeODMT (5-methoxydimethyltryptamine) induced over three head twitches per subject per 4-minute scoring period in over $99 \%$ of subjects. Test compound or vehicle ( $N=6$ per dose) was injected $P O 60$ minutes before 5-MeODMT (15 mg/kg SC). Beginning $6 \mathrm{~min}-$ utes later, head twitches were counted for 4 minutes. Fewer than three head twitches indicated antagonism (all-or-none criterion).

Antagonism of 5-HTP-Induced Wet Dog Shakes in Rat. Test compound or vehicle ( $N=6$ per dose) was injected PO 20 minutes before 5-HTP (5-hydroxytryptophan, $320 \mathrm{mg} / \mathrm{kg} \mathrm{IP}$ ), and 40 minutes later the number of whole-body "wet dog shakes" in a 15-minute observation period were counted. The number of shakes in the test compound groups was compared to the number in the vehicle group to calculate percent antagonism and $\mathrm{ED}_{50}$ values.

\section{Tests That Predict EPS Liability}

Induction of Catalepsy in Mouse. 60 minutes after $1192 \mathrm{U} 90$ or vehicle was injected PO $(N=6)$, each subject was placed with forepaws on top of a 1-inch-high rubber stopper and scored cataleptic if it remained there for $15 \mathrm{sec}$ (all-or-none criterion).
Antagonism of Apomorphine-Induced Stereotypy in Mouse. Stereotypy was assessed in the subjects being observed for apomorphine-induced climbing. Stereotypy was scored as follows: resting or moving about cage without constant sniffing, 0; hyperactivity with constant sniffing, 1; hyperactivity, sniffing, and licking, 2; licking and biting of mesh, 3; intense gnawing of mesh, 4 .

\section{Antagonism of Apomorphine-Induced Stereotypy in}

Rat. Test compound ( $N=5$ per dose) or vehicle ( $N=$ 1) was injected, and subjects were placed individually in round wire observation cages. 60 minutes later, apomorphine $(1 \mathrm{mg} / \mathrm{kg} \mathrm{SC})$ was injected, and stereotypy was scored at 5, 10, 20, 30, 40, 50, and 60 minutes. Scoring was as follows: no stereotypy, 0 ; sniffing with hyperactivity, 1 ; licking and chewing with hyperactivity, 2 ; chewirig or gnawing in one location, 3. Scores were averaged across observation times for each subject, and the means for all subjects were averaged to obtain a group mean. Subjects injected with vehicle 60 minutes before apomorphine consistently have an average score of 1 . One vehicle-treated subject was included with each group to ensure that the apomorphine was inducing stereotypy. Percent antagonism was calculated by comparing scores of test compound subjects to the average historical score of 1 .

\section{Tests That Predict Anxiolytic Efficacy}

Punished Lever Pressing in Rat. Each of 12 Coulbourn operant chambers inside sound-attenuating enclosures was equipped with a pellet dispenser (45-mg Formula $P$ pellets, P. J. Noyes Co., Lancaster, NH); an intelligence panel with a house light at the upper center, a feeder bin at the lower center, a lever manipulandum at the lower left, and a cue light (three bulbs functioning together) just above the lever; and a grid floor to which a Coulbourn shocker delivered $60-\mathrm{Hz}$ 500-msec pulses through a custom-made current intensity stepper. Control and data acquisition were done by a Data General NOVA $3 / 12$ minicomputer with a BRS/LVE InterAct interface.

Subjects received daily 1-hour sessions in the operant chambers Sunday through Friday, with 1 hour of access to food (PROLAB Rat, Mouse, Hamster 3000, Agway Country Foods, Syracuse, NY) immediately postsession and 2 hours on Saturday. The schedule of food reinforcement for lever pressing was the same as that used in previous studies (Pollard et al. 1992; see Pollard and Howard 1979 and Geller and Seifter 1960 for background). It consisted of four periods of variable-interval (VI) reinforcement, in which a pellet was delivered for a lever press every 2 minutes on the average (the "unpunished" period), and four interspersed 3-minute periods of fixed-ratio (FR) 1 reinforcement, with the cue light on, in which a pellet was delivered for each lever 
press and a simultaneous electric shock was delivered to the grid floor (the "punished" or "conflict" period) with the following limitations: The first lever press in a punished period produced no shock, the second produced $0.05 \mathrm{~mA}$, and each lever press thereafter incremented the intensity by $0.05 \mathrm{~mA}$, to a maximum of 0.70 $\mathrm{mA}$; the shock intensity was reset to $0.00 \mathrm{~mA}$ at the beginning of each of the four punished periods in a session. The schedule may be designated mult VI 2-minute (food) FR 1 (food + shock). In addition, the first lever press in a session always produced a pellet.

Drug tests occurred on Tuesdays and Fridays; Mondays and Thursdays were baseline days. Compounds (same sources as for pigeons below) were suspended in $0.5 \%$ methylcellulose. Chlordiazepoxide (Sigma Chemical Co., St. Louis, MO) was dissolved in physiological saline. All compounds were injected PO 60 minutes before the test session. For $1192 \mathrm{U} 90(N=12)$, clozapine $(N=$ $12)$, and risperidone $(N=11)$, half of the subjects received one dose and the other half a different dose on a giv'en test day. Chlordiazepoxide $25 \mathrm{mg} / \mathrm{kg}$, which produces a maximal antipunishment effect in this preparation, was given to all subjects in a group on the same day. Lever presses per session in the unpunished and punished periods were recorded. The control value for each subject was the mean for the baseline days that preceded each test day (that is, one day for each of the three doses and one day for chlordiazepoxide). Values for each test compound were subjected to an ANOVA for within-subject differences $(p<.05)$. Where a main effect was significant, the effect of each dose was compared to baseline by Dunnett's test (SigmaStat, Jandel Scientific, San Rafael, CA). Values for the one dose of chlordiazepoxide were compared to baseline by Student's $t$-test.

Punished Key Pecking in Pigeon. Testing was done in standard Coulbourn operant chambers inside sound-attenuating enclosures with white noise and ventilation fans (Coulbourn Instruments, Allentown, PA). The intelligence panel of each chamber contained a house light centered $1 \mathrm{~cm}$ below the ceiling, a response key 5 $\mathrm{cm}$ below the house light, and, at the bottom, an illuminable food trough to which access to pellets (Purina Pigeon Chow Checkers) was given for 3-sec cycles. Electric shocks ( $60 \mathrm{~Hz}, 1.5$ to $5.5 \mathrm{~mA}, 250 \mathrm{msec}$ ) were delivered through stainless steel electrodes implanted around the pubis bone (Azrin 1959). Control and data acquisition were done by a Data General NOVA 3/12 minicomputer with a BRS/LVE InterAct interface.

We followed the procedure of Barrett et al. (1986) with minor changes. Subjects were maintained at $80 \%$ of free feeding body weight. We used an autoshaping procedure to train the subjects to key-peck; then the ratio was gradually increased until responding occurred reliably under an FR 30 schedule of food reinforcement.
The 39-minute daily session (Monday through Friday) consisted of 10 alternating 3-minute components, five with the key red and five with the key white, with a 1 -minute period of darkness (timeout) between components. Once responding was stable in the presence of either color, punishment was introduced. Punishment consisted of presenting shock along with food upon completion of a ratio in the presence of the red light. Shock level was adjusted individually to suppress responding by at least $80 \%$ during the red light. When unpunished and punished baseline response rates were stable, drug testing was begun.

Buspirone (gift from Bristol-Myers, Wallingford, CT) was dissolved in isotonic saline. Clozapine (gift from Sandoz Pharmaceuticals, East Hanover, NJ), risperidone (gift from Janssen Pharmaceutica, Beerse, Belgium), and 1192U90 were dissolved in isotonic saline with a drop of Tween 80 per $5 \mathrm{ml}$ and sonicated. Injections were given into the pectoral muscle in a volume of $1 \mathrm{ml} / \mathrm{kg} 15$ minutes presession on Tuesdays and Fridays. Mondays and Thursdays were control days. Most doses were tested twice in a subject, and the average of the two determinations was taken as the basic datum. Each drug was tested in at least four subjects, and data were presented as mean responses completed in the punished or unpunished component. An effect was considered significant if its mean was more than two standard errors from the baseline mean.

Cork Gnawing in Rat. The test cage array was similar to that previously reported (Pollard and Howard 1991; Pollard et al. 1992). The test cages were ordinary single rat housing cages located above the home cages in the same rack. Like the home cage, a test cage was made of stainless steel, with a wire mesh bottom and front and a hole in the back that admitted a water spout, which was blocked by a steel cap. Test cage dimensions were $17 \times 18 \times 24 \mathrm{~cm}$ (floor area $432 \mathrm{~cm}^{2}$ ). The no. 11 cork stoppers (Krackeler Scientific, Durham, NC) weighed 2 to $2.99 \mathrm{~g}$.

A session consisted of placing the subject in the test cage with a cork for 30 minutes at midday Monday through Friday. Compounds (same sources as for the other anxiolytic tests) were suspended in $0.5 \%$ methylcellulose and injected $\mathrm{PO}$ in a volume of $1 \mathrm{ml} / \mathrm{kg}$ of body weight 30 minutes before the session on Tuesdays and Fridays; vehicle was tested similarly. Mondays and Thursdays were baseline days. All subjects in a group received the same treatment on a given day. 1192U90 was tested in a group of seven subjects, risperidone in another group of eight. Each cork was weighed to the nearest $0.01 \mathrm{~g}$ before and after the session, and the difference was taken as the basic datum. The median of all baseline days for a subject within a drug test period (about 4 weeks) was used as a control value. Drug and vehicle effects for each subject were assessed as the dif- 
Table 1. Behavioral Effects of $1192 \mathrm{U} 90$ and Three Reference Antipsychotics in Mouse (in ED:05 mg/kg PO; $95 \%$ confidence limits)

\begin{tabular}{lcccc}
\hline Compound & Climbing Antagonism & Stereotypy Antagonism & Head Twitch Antagonism & Catalepsy Induction \\
\hline $1192 \mathrm{~L} 90$ & $10.1(5.2-19.3)$ & $91.1(17.6-471.5)$ & $5.0(3.6-6.9)$ & $192.4(98.4-375.9)$ \\
Risperidone & $0.8(0.4-1.2)$ & $2.2(1.5-3.4)$ & $0.03(0.02-0.05)$ & $1.8(0.9-3.4)$ \\
Clozapine & $22.5(12.8-39.8)$ & $78.8(56.1-110.9)$ & $6.6(3.2-13.6)$ & $161.2(98.7-263.3)$ \\
Haloperidol & $0.2(0.1-0.3)$ & $0.7(0.4-1.0)$ & $4.0(3.2-4.9)$ & $3.3(1.9-5.9)$ \\
\hline
\end{tabular}

ference between the value on test day and control. The differences were subjected to the Wilcoxon matchedpairs signed-ranks test (Siegel 1956) and were considered significant if $p<.05$.

\section{RESULTS}

Table 1 gives $\mathrm{ED}_{5(\mathrm{~S} S \mathrm{PO}}$ for $1192 \mathrm{U90}$ ) and the three standard antipsychotics in mouse tests that predict antipsychotic efficacy and side effects. Table 2 gives $E_{50} \mathrm{SO}$ in rat tests. Figures 2, 3, and 4 give dose-effect curves for antipsychotic activity and side-effect liability. Figures 5, 6, and 7 give anxiolytic dose-effect curves.

\section{Tests That Predict Antipsychotic Efficacy}

Antagonism of Apomorphine-Induced Climbing in Mouse. $\quad 1192$ U90 was tested over a dose range of 1 to $120 \mathrm{mg} / \mathrm{kg}$ PO. Results from all experiments were combined to calculate a grand average $E D_{50}$ of $10.1 \mathrm{mg} / \mathrm{kg}$ for climbing and $91.1 \mathrm{mg} / \mathrm{kg}$ for stereotypy. Table 1 gives comparable values for the three standards. Risperidone and haloperidol, with $E D_{-i)}$ of 0.8 to $0.2 \mathrm{mg} /$ $\mathrm{kg} \mathrm{PO}$, were more potent than 1192L90; clozapine, with $\mathrm{ED}_{50}$ of $22.5 \mathrm{mg} / \mathrm{kg} \mathrm{PO}$, was approximately half as potent as 1192 U90. Figure 2 shows that 1192 U90 0.3 to 20 $\mathrm{mg} / \mathrm{kg}$ injected SC also antagonized apomorphine-induced climbing (two experiments, $N=48$ ), with $\mathrm{ED}_{50}$ of $0.6 \mathrm{mg} / \mathrm{kg}$.

Antagonism of Apomorphine-Induced Circling in Rats with Unilateral Striatal Lesions. Figure 3 shows that $1192 \mathrm{U} 90$ (5 to $40 \mathrm{mg} / \mathrm{kg}$ PO) antagonized circling, with an $\mathrm{ED}_{\overline{3} \text { () }}$ of $7.9 \mathrm{mg} / \mathrm{kg}$. Table 2 gives comparable values for the three standards. Clozapine, with an $E D_{50}$ of 12.2 $\mathrm{mg} / \mathrm{kg} \mathrm{PO}$, antagonized apomorphine-induced circling less potently. Risperidone and haloperidol, with $\mathrm{ED}_{50 \mathrm{~S}}$ of 0.8 and $0.3 \mathrm{mg} / \mathrm{kg} \mathrm{PO}$, were more potent than 1192 U90.

Antagonism of Amphetamine-Induced Hyperlocomotion in Rat. Figure 3 shows that 1192 U90 (1.25 to 20 $\mathrm{mg} / \mathrm{kg}$ ) antagonized hyperlocomotion, with an ED 50 of $6.6 \mathrm{mg} / \mathrm{kg}$. Clozapine ( 5 to $30 \mathrm{mg} / \mathrm{kg}$ ) antagonized hyperlocomotion, with an $\mathrm{ED}_{50}$ of $21.5 \mathrm{mg} / \mathrm{kg}$. Risperidone and haloperidol were not tested.

Conditioned Avoidance Response in Rat. Figure 4 shows effects on avoids and omits (escape failures). All four compounds significantly reduced avoids: for 1192U90, $F(3,15)=25.9, p<.001$; for clozapine, $F(3,15)=17.9, p<$ .001 ; for risperidone, $F(4,20)=16.6, p<.001$; for haloperidol $F(3,15)=50.9, p<.001$. All four compounds significantly increased omits: for 1192 U90, $F(3,15)=$ $4.90, p=.014$; for clozapine, $\chi^{2}(3)=16.0, p=.001$; for risperidone, $\chi^{2}(4)=11.9, p=.019$; for haloperidol, $\chi^{2}(3)=$ $17.7, p<.001$. Individual dose effects for avoids and omits that were significantly different from baseline are indicated by asterisks in Figure 4; no dose of risperidone significantly increased omits, but the values for $1.6 \mathrm{mg} / \mathrm{kg}$ were $0,0,7,39,64$, and 83 . Clozapine and haloperidol decreased intertrial crosses: for 1192U90, $F(3,15)=0.106, p=.955$; for clozapine, $F(3,15)=7.72$, $p=.002$, with all three doses significantly lower than baseline; for risperidone, $F(4,20)=2.00, p=.134$; for haloperidol, $F(3,15)=16.2, p<.001$, with all three doses significantly lower than baseline. Table 2 gives $\mathrm{ED}_{70}$ s for avoids $\mathrm{PO}$.

192 U90 injected SC significantly reduced avoids: $F(4$, 20) $=6.68, p<.001$, with 0.8 and $1.6 \mathrm{mg} / \mathrm{kg}$ signifi-

Table 2. Behavioral Effects of $1192 \mathrm{U} 90$ ) and Three Reference Antipsychotic in Rat (in ED5() $\mathrm{mg} / \mathrm{kg} \mathrm{PO} ; 95 \%$ confidence limits)

\begin{tabular}{lccccc}
\hline Compound & $\begin{array}{c}\text { Circling } \\
\text { Antagonism }\end{array}$ & $\begin{array}{c}\text { Conditioned } \\
\text { Avoidance }\end{array}$ & $\begin{array}{c}\text { Hyperlocomotion } \\
\text { Antagonism }\end{array}$ & $\begin{array}{c}\text { 5-HTP } \\
\text { Antagonism }\end{array}$ & $\begin{array}{c}\text { Stereotypy } \\
\text { Antagonism }\end{array}$ \\
\hline 11 192L90 & $7.9(3.0-20.5)$ & 5.7 & $6.6(3.1-14.2)$ & $4.6(2.1-10.1)$ & $133.4(38.3-464.6)$ \\
Risperidone & $0.8(0.4-1.7)$ & 0.3 & & $0.1(0.05-0.3)$ & $1.5(0.8-2.8)$ \\
Clozapine & $12.2(3.4-4+.4)$ & 10.0 & $21.5(13.8-33.6)$ & $3.8(1.2-12.3)$ & $>100.0$ \\
Haloperidol & $0.3(0.2-0.5)$ & 0.2 & & $3.2(1.1-9.4)$ & $0.4(0.1-0.9)$ \\
\hline
\end{tabular}




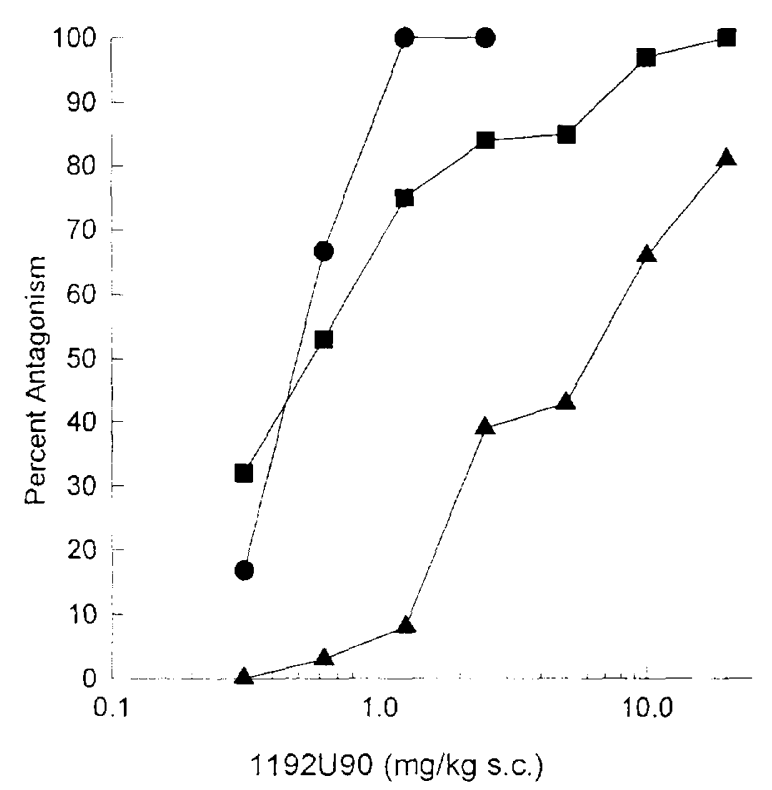

Figure 2. 1192L90 SC antagonized 5-HT- and DA-induced behaviors in mouse. Circles, head twitches induced by the 5-HT agonist 5-MeODMT; $1192 \mathrm{U}_{90} \mathrm{ED}_{50}$ (95\% confidence limits $)=0.5(0.3-0.7) \mathrm{mg} / \mathrm{kg}$. Squares, climbing induced by apomorphine; $\mathrm{ED}_{70}=0.6(0.2-1.4) \mathrm{mg} / \mathrm{kg}$. Triangles, stereotypy induced by apomorphine; $\mathrm{ED}_{50}=5.6(2.5-12.9) \mathrm{mg} / \mathrm{kg}$. 1192 U90 was more potent against limbic DA activation (squares) than striatal DA activation (tringeles).

cantly lower than baseline; the $\mathrm{ED}_{50}$ was $1.4 \mathrm{mg} / \mathrm{kg}$. These doses did not significantly change intertrial crosses or omits: $F(4,20)=1.43, p=.261 ; \chi^{2}(4)=2.33, p=$ .675 .

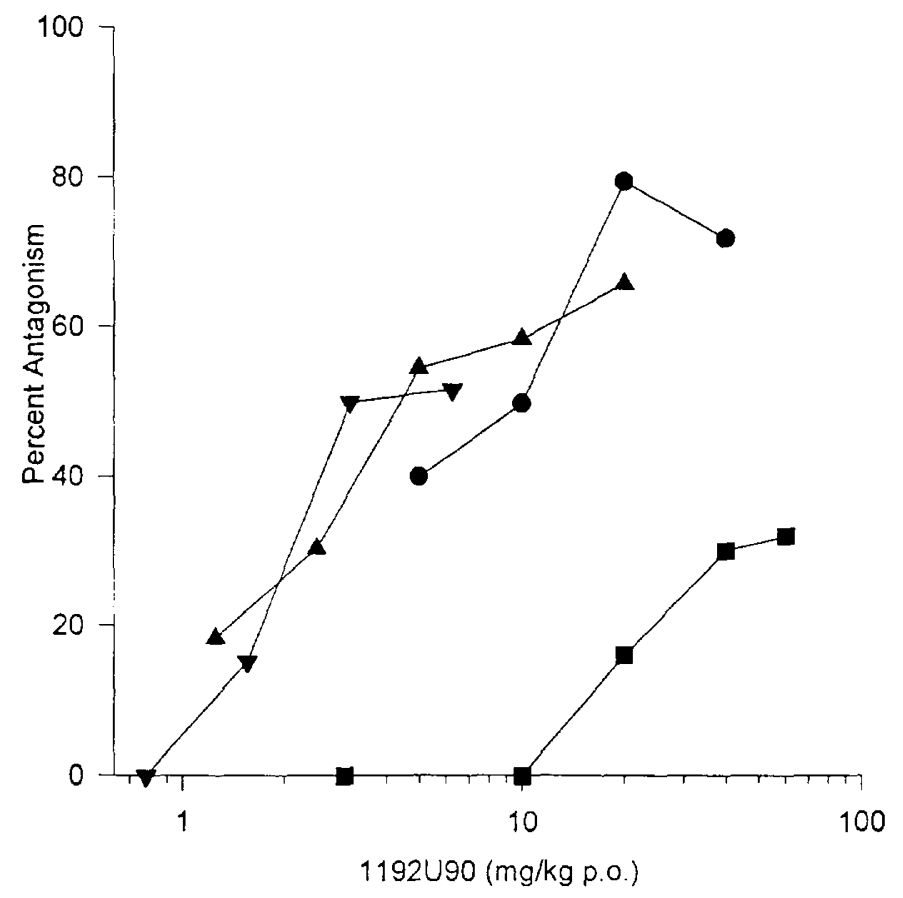

\section{Tests That Predict 5- $\mathrm{HT}_{2}$ Receptor Antagonism}

Antagonism of 5-MeODMT-Induced Head Twitches in Mouse. Figure 2 shows that $1192 \mathrm{U} 90$ antagonized head twitches, with an $E_{50}$ of $0.5 \mathrm{mg} / \mathrm{kg}$ SC. The $\mathrm{ED}_{50}$ $\mathrm{PO}$ was $5 \mathrm{mg} / \mathrm{kg}$. Risperidone, haloperidol, and clozapine all antagonized head twitches, with $\mathrm{ED}_{50} \mathrm{~s}$ of 0.03 , 4 , and $6.6 \mathrm{mg} / \mathrm{kg}$ PO, respectively (Table 1 ).

Antagonism of 5-HTP-Induced Wet Dog Shakes in Rat. Figure 3 shows that $1192 \mathrm{U} 90$ antagonized wet dog shakes, with an $E_{50}$ of $4.6 \mathrm{mg} / \mathrm{kg}$ PO. Table 2 gives $\mathrm{ED}_{50} \mathrm{~s}$ for risperidone, haloperidol, and clozapine.

\section{Tests That Predict EPS Liability}

Induction of Catalepsy in Mouse. The $\mathrm{ED}_{50}$ of $1192 \mathrm{U} 90$ for catalepsy was $192.4 \mathrm{mg} / \mathrm{kg}$ PO. Table 1 gives comparable values for the three standards. Ratios of catalepsy $E D_{50}$ to antagonism of apomorphine-induced climbing $E_{50}$ for 1192U90, clozapine, risperidone, and haloperidol were $19,7,2$, and $17 \mathrm{mg} / \mathrm{kg}$, respectively.

Antagonism of Apomorphine-Induced Stereotypy in Mouse. Table 1 and Figure 2 show that 1192 U90 antagonized stereotypy, with ED50s of $91.1 \mathrm{mg} / \mathrm{kg}$ PO and $5.6 \mathrm{mg} / \mathrm{kg}$ SC. Table 1 gives comparable values for the three standards. Ratios of stereotypy antagonism ED 50 to climbing antagonism $\mathrm{ED}_{50}$ for $1192 \mathrm{U} 90 \mathrm{PO}$ and SC were 9 and 9. Ratios (PO) for clozapine, risperidone, and haloperidol were 4,3 , and 4, respectively.

Antagonism of Apomorphine-Induced Stereotypy in Rat. 1192 U90 antagonized only weakly stereotypy in rat, with a calculated $\mathrm{ED}_{50}$ of $133.4 \mathrm{mg} / \mathrm{kg} \mathrm{PO}(50 \%$ antagonism not achieved; Figure 3). Table 2 gives compa-

Figure 3. 1192 U90 PO antagonized 5-HT and DA agonists in rat. Downuard pointing triangles, wet dog shakes induced by the 5-HT agonist 5-HTP; 1192 U90 ED 50 (95\% confidence limits) $=4.6(2.1-10.1) \mathrm{mg} / \mathrm{kg}$. Upward pointing triangles, d-amphetamine-induced locomotor activity; $E_{50}=6.6(3.1-14.2) \mathrm{mg} / \mathrm{kg}$. Circles, apomorphine-induced contralateral circling in rats with unilateral 6-OHDA lesions; $\mathrm{ED}_{50}=7.9(3.0-20.5) \mathrm{mg} / \mathrm{kg}$. Squares, apomorphine-induced stereotypy; only $32 \%$ antagonism occurred at the highest dose tested, $60 \mathrm{mg} / \mathrm{kg}$. $1192 \mathrm{U} 90$ was more potent against limbic DA activation (uproard pointing triangles) than striatal DA activation (sifunres). 
Figure 4. Antagonism by $1192 \mathrm{U} 90$ and three reference antipsychotics of conditioned avoidance in rats. Filled circles, number of avoids; open circles, number of avoidance failures in the 100-trial session. The leftmost data points for each compound indicate baseline values. $p<.05$ by Dunnett's test following ANOVA (mean \pm SEM).

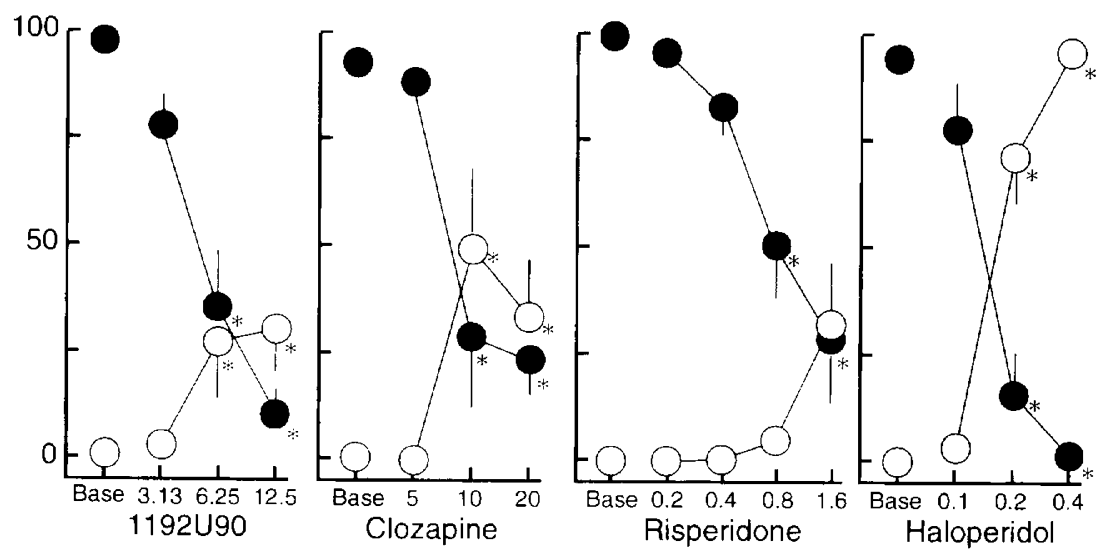

rable values for the three standards. Risperidone and haloperidol antagonized stereotypy, but clozapine at $100 \mathrm{mg} / \mathrm{kg}$ PO did not.

\section{Tests That Predict Anxiolytic Efficacy}

Punished Lever Pressing in Rat. Figure 5 shows the effects of 1192U90, risperidone, and clozapine. 1192 U90 increased punished responding: $F(3,11)=2.91, p=$ .0492 . The maximal effect, at $12.5 \mathrm{mg} / \mathrm{kg}$, was $21 \%$ above baseline. $1192 \mathrm{U} 90$ also decreased unpunished responding: $F(3,11)=5.07, p=.005 t$. In these subjects, chlordiazepoxide increased punished responding by $78 \%$.

Risperidone did not change punished responding significantly: $F(3,11)=1.75, \mu=.1780$. The nonsignificant effect of $0.4 \mathrm{mg} / \mathrm{kg}$ was $13^{\prime \prime}$, above baseline. It did change unpunished responding: $F(3,11)=8.20, p=$ .0004 . In these subjects, chlordiazepoxide increased punished responding by $55^{\circ} \%$. Risperidone $(0.8 \mathrm{mg} / \mathrm{kg})$ was tested in six subjects; it reduced punished responding by $68^{\circ} \circ=9^{\circ} \%$ and reduced unpunished responding by $95^{\circ} \% \pm 2^{\circ} \cdots$
Clozapine did not change punished responding significantly: $F(3,11)=0.787, p=.5100$. The nonsignificant effect of $25 \mathrm{mg} / \mathrm{kg}$ was $15 \%$ above baseline. It did decrease unpunished responding: $F(3,11)=4.87, p=$ .0065 . In these subjects, chlordiazepoxide increased punished responding by $56 \%$. Clozapine $50 \mathrm{mg} / \mathrm{kg}$ was tested in six subjects; it decreased punished responding nonsignificantly by $25 \% \pm 25 \%$ and decreased unpunished responding by $77 \% \pm 11 \%$.

Punished Key Pecking in Pigeon. Figure 6 shows the effects of 1192U90, risperidone, and clozapine. 1192U90 at 0.1 and $1 \mathrm{mg} / \mathrm{kg}$ significantly increased punished responding. The maximal effect, at $3 \mathrm{mg} / \mathrm{kg}$, was $95 \%$ of buspirone's effect. No dose of $1192 \mathrm{U} 90$ decreased unpunished responding.

At 1 and $10 \mathrm{mg} / \mathrm{kg}$ risperidone significantly increased punished responding. The maximal effect, at 1 $\mathrm{mg} / \mathrm{kg}$, was $30 \%$ of buspirone's effect. Unpunished responding at all doses was below the baseline rate, although not significantly.
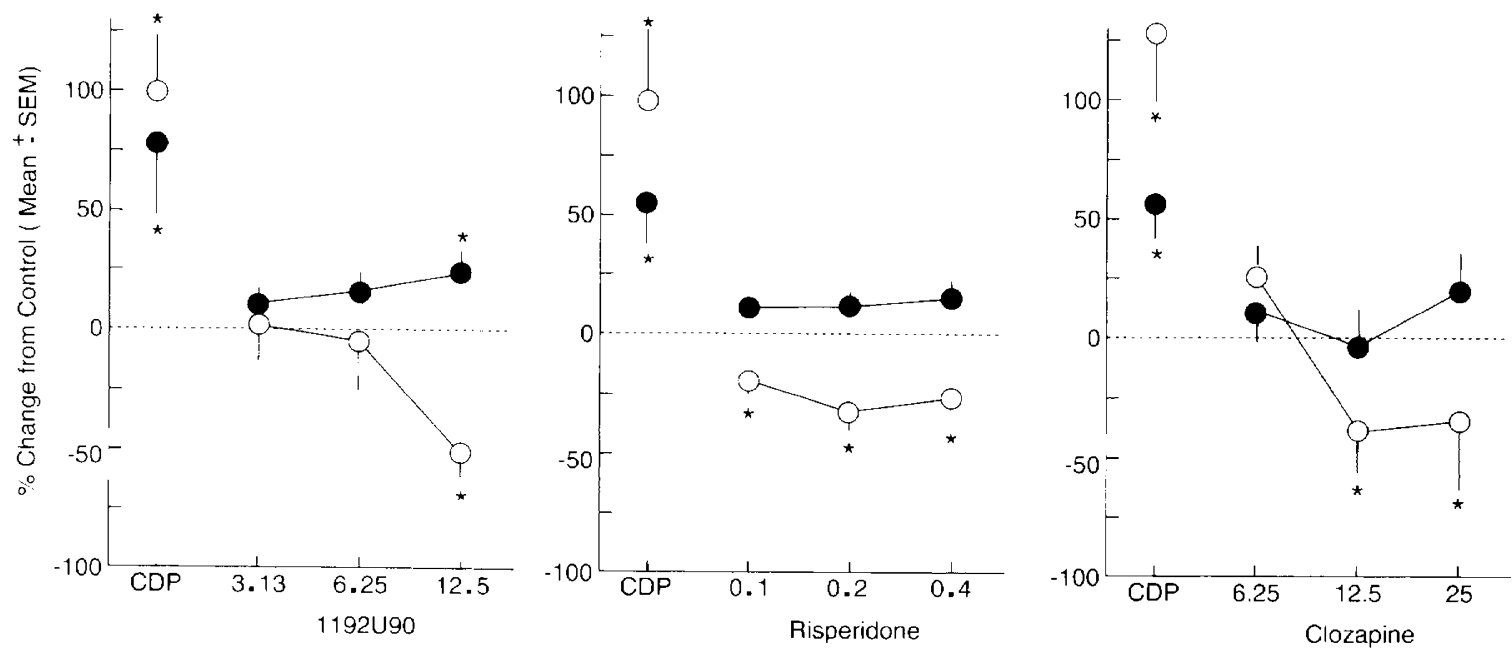

Figure 5. Effects of $1192 \mathrm{~L} 90$, risperidone, and clozapine on punished (fillet circles) and unpunished (open circles) lever pressing by rats (doses in $\mathrm{mg} / \mathrm{kg}$ PO). CDP, chlordiazepoxide $25 \mathrm{mg} / \mathrm{kg}$. 

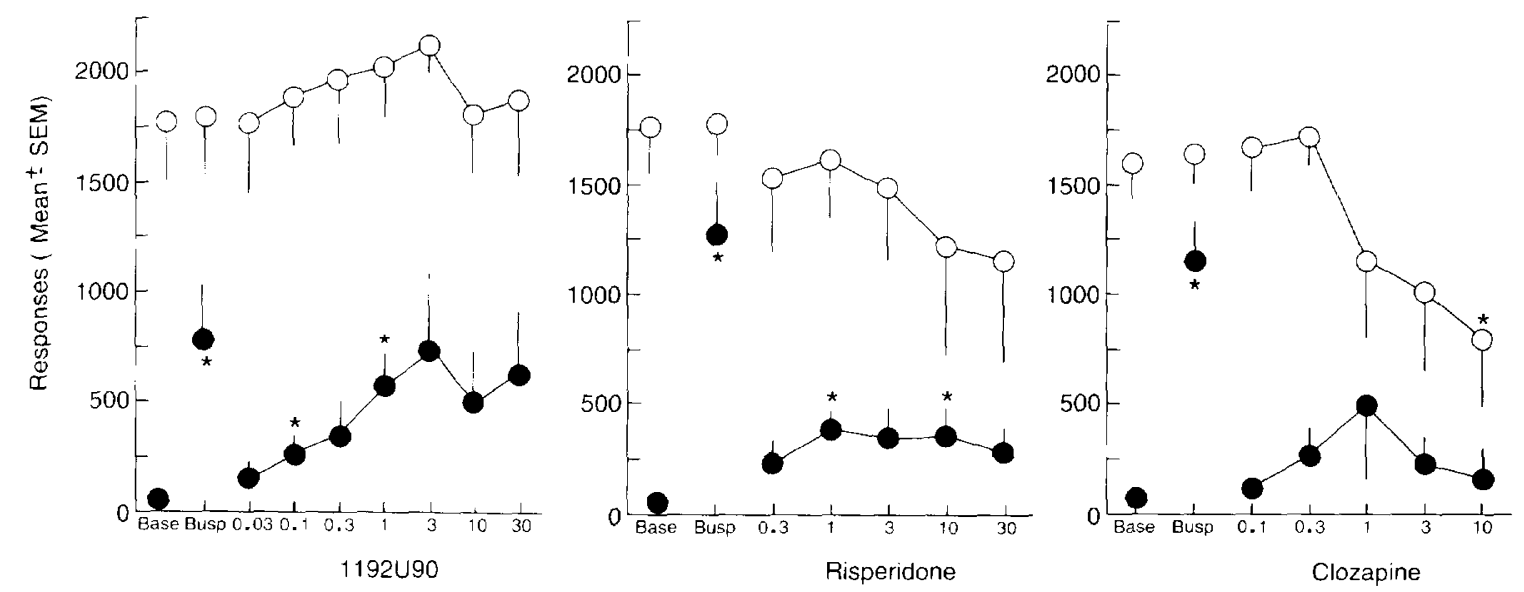

Figure 6. Effects of 1192U90, risperidone, and clozapine on punished (filled circles) and unpunished (open circles) key pecking by pigeons (doses in $\mathrm{mg} / \mathrm{kg} \mathrm{IM}$ ). Busc, baseline control; Busp, buspirone $1 \mathrm{mg} / \mathrm{kg}$.

Clozapine increased punished responding moderately but not significantly. The maximal effect, at $1 \mathrm{mg} /$ $\mathrm{kg}$, was $43 \%$ of buspirone's effect. Clozapine produced a dose-related decrease in unpunished responding; the effect was significant at $10 \mathrm{mg} / \mathrm{kg}$.

Cork Gnawing in Rat. Figure 7 gives median values for baseline, vehicle, and buspirone $3.13 \mathrm{mg} / \mathrm{kg}$ for each group, and values for five doses of 1192 U90 and four doses of risperidone.

In the 1192U90 group, buspirone increased gnawing by an unusually large amount, to $0.61 \mathrm{~g}$ (range 0.16-1.96 g). Values for the two highest doses of 1192U90 were $0.28 \mathrm{~g}$ (range $0.14-0.85 \mathrm{~g}$ ) and $0.25 \mathrm{~g}$ (range $0.00-1.88 \mathrm{~g}$ ). A dose of $12.5 \mathrm{mg} / \mathrm{kg}$ produced mild sedation.

In the risperidone group, buspirone produced a typical increase to $0.30 \mathrm{~g}$ (range $0.14-0.48 \mathrm{~g}$ ). One subject's values for the four doses of risperidone were $0.18 \mathrm{~g}, 0.13$ $\mathrm{g}, 0.97 \mathrm{~g}$, and $0.01 \mathrm{~g}$; the range for all other subjects was
0.00 to $0.13 \mathrm{~g}$. One $\mathrm{mg} / \mathrm{kg}$ produced sedation and reduced gnawing significantly.

\section{DISCUSSION}

All antipsychotics antagonize $\mathrm{D}_{2}$ receptors (Creese et al. 1976). Limbic DA receptors are thought to be involved in schizophrenia, and antagonism of these receptors is thought to be critical for antipsychotic effect (White and Wang 1983); antagonism of apomorphine-induced climbing in mouse reflects antagonism of limbic DA receptors (Costall et al. 1981; Kelly et al. 1975). Unilateral depletion of striatal DA with 6-OHDA sensitizes DA receptors, and low doses of DA agonists induce circling or turning contralateral to the depleted side; antipsychotics antagonize this circling (Ungerstedt et al. 1974; Ljungberg and Ungerstedt 1978). Amphetamine in-
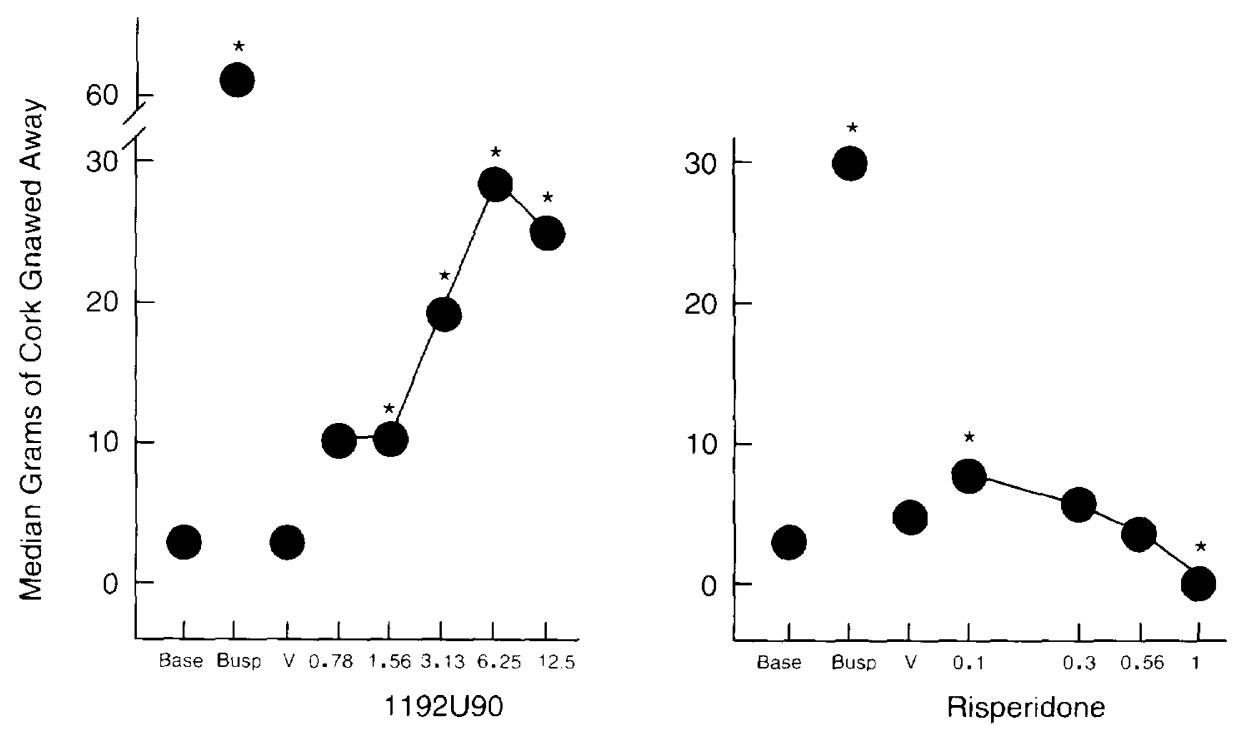

Figure 7. Effects of $1192 \mathrm{U} 90$ and risperidone on cork gnawing in rats (doses in $\mathrm{mg} / \mathrm{kg} \mathrm{PO}$ ). Base, baseline control; Busp, buspirone $3.13 \mathrm{mg} / \mathrm{kg} ; V$, vehicle. 
duces hyperlocomotion by stimulating limbic DA receptors; antipsychotics antagonize this hyperlocomotion (Costall and Naylor 1976). 1192U90 antagonized the effects of a DA agonist in these three tests, with $\mathrm{ED}_{50 \mathrm{~S}}$ ranging from 6 to $10 \mathrm{mg} / \mathrm{kg}$ PO. Antipsychotics also inhibit conditioned avoidance responding; $1192 \mathrm{U} 90$ inhibited avoidance, with an $\mathrm{ED}_{50}$ of $5.7 \mathrm{mg} / \mathrm{kg} P O$ and $1.4 \mathrm{mg} / \mathrm{kg}$ SC. 1192U90 PO was less potent than risperidone or haloperidol but more potent than clozapine. 1192 U90 was 10 to 16 times more potent SC than PO, which confirmed pharmacokinetic data that showed poor bioavailability in mouse and rat (data on file at Glaxo Wellcome, Inc.)

Meltzer et al. (1989) and others (Altar et al. 1986) have proposed that compounds that antagonize $5-\mathrm{HT}_{2}$ receptors more potently than $\mathrm{D}_{2}$ receptors induce less EPSs and are effective for negative or deficit symptoms as well as positive symptoms of schizophrenia. In vitro, $1192 \mathrm{U} 90$ was found to bind to $5-\mathrm{HT}_{2}$ receptors more potently than to $\mathrm{D}_{2}$ receptors (Jones-Humble et al. 1996). In vivo, it antagonized the behavioral effects of $5-\mathrm{HT}_{2}$ stimulation, with an $\mathrm{ED}_{50}$ of $5 \mathrm{mg} / \mathrm{kg} \mathrm{PO}$ and of 0.5 $\mathrm{mg} / \mathrm{kg} \mathrm{SC}$ in mouse and $4.6 \mathrm{mg} / \mathrm{kg} \mathrm{PO}$ in rat. In both species, $1192 \mathrm{U} 90$ antagonized $5-\mathrm{HT}_{2}$ stimulation at doses lower than those that antagonized $\mathrm{D}_{2}$ stimulation; the relationship was the same for the so-called atypical antipsychotics risperidone and clozapine. Differences in potency for $\overline{5}-\mathrm{HT}_{2}$ antagonism and $\mathrm{D}_{2}$ antagonism in vivo were not as great for $1192 \mathrm{U} 90$ as for risperidone and clozapine. The typical antipsychotic haloperidol, on the other hand, showed much more potent $\mathrm{D}_{2}$ than $5-\mathrm{HT}_{2}$ antagonism in vivo.

Antagonism of apomorphine-induced stereotypy and induction of catalepsy reflect DA antagonism in the extrapyramidal motor system and predict liability for EPSs (Costall and Naylor 1973; Worms and Lloyd 1979). $\mathrm{ED}_{50 \mathrm{~s}}$ for $1192 \mathrm{U} 90$ in these tests were much higher than $\mathrm{ED}_{50} \mathrm{~S}$ in the tests that predict antipsychotic efficacy. Ratios of $E D_{5(1)}$ for $E P S$ liability to $E D_{51}$ s for efficacy were higher for 1192U90 than for clozapine, risperidone, and haloperidol in mouse and higher than for risperidone and haloperidol in rat. These high ratios for 1192 U90 relative to risperidone, which is also a $5-\mathrm{HT}_{2} / \mathrm{D}_{2}$ antagonist, may result from $1192 \mathrm{U} 90$ 's potent $5-\mathrm{HT}_{1 \mathrm{~A}}$ agonist activity (Jones-Humble et al. 1996) in combination with its favorable $5-\mathrm{HT}_{2}$ antagonism to $\mathrm{D}_{2}$ antagonism ratio. A 5-HT 1 A agonist decreased the catalepsy induced by typical antipsychotics in rat (McMillen et al. 1988) and decreased EPSs induced by typical antipsychotics in man (Goff et al. 1991).

Potent adrenergic $\alpha_{1}$ antagonism by $1192 \mathrm{U} 90\left(K_{\mathrm{i}}=\right.$ $0.3 \mathrm{nM}$ ) could produce hypotension and orthostatic hypotension, which may be its major side effects. Other antipsychotics, such as clozapine and risperidone, also are potent $\alpha_{1}$ antagonists. Their hypotensive effects are controlled by titrated dosing upon initiation of therapy.
Tolerance to this effect usually develops rapidly. Baldessarini et al. (1992) and others (Van Kammen and Kelley 1991) have postulated that $\alpha$ antagonism is necessary for relief of psychosis without EPSs, and this property of 1192 U90 may be beneficial as well.

None of the three compounds produced a substantial increase in punished lever pressing in rat. Thus there is no reason to expect rapid-onset anxiolysis. Clozapine and olanzapine have been reported to increase punished behavior moderately (see Nanry et al. 1995), although the increases were of lesser magnitude than those produced by the established sedative-hypnotic anxiolytics. The apparent increase of punished key pecking by clozapine (Figure 6) did not meet the criterion for significance, but at $1 \mathrm{mg} / \mathrm{kg}$ it reached nearly half the magnitude of buspirone's effect in the same pigeons, which makes the effect roughly comparable to the moderate published effects.

1192 U90 was active in two behavioral tests that predict delayed-onset anxiolysis: It increased punished responding in pigeon and cork gnawing in rat. Anxiolysis would be beneficial for maintenance therapy of schizophrenia, because psychotic episodes are often triggered by stress (Liberman and Corrigan 1992) and associated with anxiety (American Psychiatric Association 1987). Along with anxiolysis, antidepressent activity is also associated with 5-HT ${ }_{1 \wedge}$ agonism (Robinson et al. 1989). Because up to $75 \%$ of first diagnosed schizophrenics are depressed (Koreen et al. 1993), relief of depression also is a desirable property.

In summary, $1192 \mathrm{U} 90$ is a potential atypical antipsychotic that reverses the behavioral effects of $5-\mathrm{HT}_{2}$ agonists more potently than it reverses the behavioral ef fects of $\mathrm{D}_{2}$ agonists and, in addition, is a potent $5-\mathrm{HT}_{1 \mathrm{~A}}$ agonist. It is active $\mathrm{PO}$ in behavioral tests that predict antipsychotic efficacy at doses well below those that are active in tests that predict EPS liability in mouse and rat. This profile has been confirmed in electrophysiological tests in chronically treated rat (Jones-Humble et al. 1996). With its unique combination of receptor activities, 1192U90 may relieve negative and positive symptoms of schizophrenia and have antidepressant and anxiolytic effects that should be beneficial for maintenance therapy in schizophrenia.

\section{REFERENCES}

Altar CA, Wasley AM, Neale RF, Stone GA (1986): Typical and atypical antipsychotic occupancy of $D_{2}$ and $S_{2}$ receptors: An autoradiographic analysis in rat brain. Brain Res Bull 16:517-525

American Psychiatric Association (1987): Diagnostic and Statistical Manual of Mental Disorders, ed. 3, rev. Washington, American Psychiatric Association

Andreasen NC (1985): Positive vs. negative schizophrenia: A critical evaluation. Schizophr Bull 11:380-389 
Azrin NH (1959): A technique for delivering shock to pigeons. J Exp Anal Behav 2:161-163

Baldessarini RJ (1985): Drugs and the treatment of psychiatric disorders. In Gilman $\mathrm{AG}$, Goodman LS, Rall RW, Murad F (eds), Goodman and Gilman's The Pharmacological Basis of Therapeutics, ed 7. New York, Macmillan, pp 173-205

Baldessarini RJ, Huston-Lyons D, Campbell A, Marsh E, Cohen BM (1992): Do central antiadrenergic actions contribute to the atypical properties of clozapine? Br J Psychiatry 160 (suppl. 17):12-16

Barrett JE, Witkin JM, Mansbach RS, Skolnick P, Weissman BA (1986): Behavioral studies with anxiolytic drugs. Ill. Antipunishment actions of buspirone in the pigeon do not involve benzodiazepine receptor mechanisms. I Pharmacol Exp Ther 238:1009-1013

Bersani G, Grispini A, Marini S, Pasini A, Valducci M, Ciani $N$ (1986): Neuroleptic-induced extrapyramidal side effects: Clinical perspectives with ritanserin (R55 667), a new selective 5- $\mathrm{HT}_{2}$ receptor blocking agent. Curr Ther Res 40:492-499

Borison RL, Albrecht JW, Diamond BI (1990): Efficacy and safety of a putative anxiolvtic agent: Ipsapirone. Psvchopharmacol Bull 26:207-210

Brocco MJ, Koek W, Degryse A-D, Colpaert FC (1990): Comparative studies on the anti-punishment effects of chlordiazepoxide, buspirone, and ritanserin in the pigeon, Geller-Seifter and Vogel conflict procedures. Behar Pharmacol 1:403-418

Carlsson A (1988): The current status of the dopamine hypothesis of schizophrenia. Neuropsychopharmacology $1: 179-186$

Colpaert FC, Janssen PA (1983): The head-twitch response to intraperitoneal injection of 5-hydroxytryptophan in the rat: Antagonist effects of purported 5-hvdroxytrptamine antagonists and pirenperone, an LSD antagonist. Neuropharmacology 22:993-1000

Costall B, Naylor RJ (1973) Neuroleptic and non-neuroleptic catalepsy. Arzneimittelforschung 23:67+-683

Costall B, Naylor RJ (1976): A comparison of the abilities of typical neuroleptic agents and of thioridazine, clozapine, sulpiride and metoclopramide to antagonise the hyperactivity induced by dopamine applied intracerebrally to areas of the extrapvramidal and mesolimbic svstems. Eur J Pharmacol 40:9-19

Costall B, Naylor RJ, Nohria V (1979) Hyperactivity response to apomorphine and amphetamine in the mouse: The importance of the nucleus accumbens and caudateputamen. J Pharm Pharmacol 31:259-261

Costall B, Naylor RJ, Nohria I' (1981): Lse of the intracerebral injection technique to elucidate mechanisms of apomorphine climbing and its antagonism in the mouse. Psychopharmacology 73:91-94

Creese I, Burt DR, Snvder SH (1976): Dopamine receptor binding predicts clinical and pharmacological potencies of antischizophrenic drugs. Science 192:481-483

Geller I, Seifter J (1960): The effects of meprobamate, barbiturates, d-amphetamine and promazine on experimentally induced conflict in the rat. Psychopharmacologia $1: 482-492$
Goa KL, Ward A (1986): Buspirone: A preliminary review of its pharmacological properties and therapeutic efficacy as an anxiolytic. Drugs 32:114-129

Goff DC, Midha KK, Brotman AW, McCormick S, Waites M, Amico ET (1991): An open trial of buspirone added to neuroleptics in schizophrenic patients. J Clin Psychopharmacol 11:193-197

Goodwin GM, Green AR (1985): A behavioral and biochemical study in mice and rats of putative selective agonists and antagonists for $5-\mathrm{HT}_{1}$ and $5-\mathrm{HT}_{2}$ receptors. Br J Pharmacol 84:743-753

Howard JL, Pollard GT (1990): Effects of buspirone in the Geller-Seifter conflict test with incremental shock. Drug Dev Res 19:37-49

Jann MW (1991): Evaluations of new drugs, clozapine. Pharmacotherapy 11:179-195

Jones-Humble SA, Durcan MJ, Norton RM, Tang FLM, Russell AV, Watson MJ, Gengo PJ, Morgan PF, Wang CM, Cox RF (1996): Neurochemical and electrophysiological profile of the potential antipsychotic 1192U90. Neuropsychopharmacology 15:217-230

Koreen AR, Siris SG, Chakos M, Alvir J, Mayerhoff D, Lieberman J (1993): Depression in first-episode schizophrenia. Am J Psychiatry 150:1643-1648

Kelly PH, Seviour PW, Iversen SD (1975): Amphetamine and apomorphine responses in the rat following 6-ODHA lesions of the nucleus accumbens septi and corpus striatum. Brain Res 94:507--522

Lader M (ed) (1988): Buspirone: A New Introduction to the Treatment of Anxiety. London, Royal Society of Medicine Services

Liberman RP, Corrigan PW (1992): Is schizophrenia a neurological disorder? J Neuropsychiatry Clin Neurosci $4: 119-124$

Ljungberg T, Ungerstedt $U$ (1978): Classification of neuroleptic drugs according to their ability to inhibit apomorphine-induced locomotion and gnawing: Evidence for two different mechanisms of action. Psychopharmacology 56:239-247

Mansbach RS, Harrod C, Hoffman SM, Nader MA, Lei Z, Witkin JM, Barrett JE (1988): Behavioral studies with anxiolytic drugs. V. Behavioral and in vivo neurochemical analyses in pigeons of drugs that increase punished responding. J Pharmacol Exp Ther 246:114-120

McMillen BA, Scott SM, DaVanzo EA (1988): Reversal of neuroleptic-induced catalepsy by novel aryl-piperazine anxiolytic drugs. J Pharm Pharmacol 40:885-887

Meltzer HY (1993): New drugs for the treatment of schizophrenia. Psychiatr Clin of North Am 16:365-385

Meltzer HY, Matsubara S, Lee J-C (1989): Classification of typical and atypical antipsychotic drugs on the basis of dopamine D-1, D-2 and serotonin $2 \mathrm{pK}_{i}$ values. J Pharmacol Exp Ther 251:238-246

Moore NA, Rees G, Sanger G, Tye NC (1994): Effects of olanzapine and other antipsychotic agents on responding maintained by a conflict schedule. Behav Pharmacol 5:196-202

Nanry KP, Howard JL, Pollard GT (1991): Effects of buspirone and other anxiolytics on punished key-pecking in the pigeon. Drug Dev Res 24:269-276 
Nanry KP, Pollard GT, Howard JL (1995): Olanzapine moderately increases conflict responding but does not produce a benzodiazepine-like cue in rat. Drug Dev Res $34: 317-319$

Norman MH, Rigdon GC, Navas F IlI, Hall WR (in press). Structure-activity relationships of a series of substituted benzamides: Potent $\mathrm{D}_{2} / 5-\mathrm{HT}_{2}$ antagonists and 5-HT agonists as neuroleptic agents. J Med Chem

Ögren SO, Archer T (1994): Effects of typical and atypical antipsychotic drugs on two-way active avoidance. Relationship to DA receptor blocking profile. Psychopharmacology 114:383-391

Paxinos G, Watson C (1986): The Rat Brain in Stereotaxic Coordinates. Orlando, Academic Press

Pollard GT, Howard JL (1979): The Geller-Seifter conflict paradigm with incremental shock. Psychopharmacology $62: 117-121$

Pollard GT, Howard JL (1990): Effects of drugs on punished behavior: Pre-clinical test for anxiolytics. Pharmacol Ther 45:403-424

Pollard GT, Howard JL (1991): Cork gnawing in the rat as a screening method for buspirone-like anxiolytics. Drug Der Res 22:179-187

Pollard GT, Nanry KP, Howard JI, (1992): Effects of tandospirome in three behavioral tests for anxiolytics. Eur J Pharmacol 221:297-305

Rimon R, Kuoppasalmi K, Naukkarinen H, Lang $S$ Sandquist A, Leinonen E (1994): Clozapine decreases the level of anxiety and aggressive behavior in patients with therapy-refractory schizophrenia. Psychopharmacology 114:B7 (Abstract)

Robinson DS, Alms DR, Shrotriya RC, Messina M, Wickramarante P (1989): Serotonergic anxiolytics and treatment of depression. Psychopathology 22(suppl 1):27-36

Sandoz Pharmaceuticals (1994): Clozaril (clozapine) tablets. Physician's Desk Reference 48:2042-2046

Schwartz JT, Brotman AW (1992): A clinical guide to antipsychotic drugs. Drugs 44:981-992

Siegel S (1956): Nonparametric Statistics for the Behavioral Sciences. New York, McGraw-Hill

Ungerstedt U, Ljungberg T, Steg G (1974): Behavioral, physiological and neurochemical changes after 6-hydroxydopamine-induced degeneration of the nigro-striatal dopamine neurons. Adv Neurol 5:421-426

Van Kammen DP, Kelley M (1991): Dopamine and norepinephrine activity in schizophrenia: An integrative perspective. Schizophr Res 4:173-191

White FJ, Wang RY (1983): Differential effects of classical and atypical antipsychotic drugs on $\mathrm{A} 9$ and $\mathrm{A} 10$ dopamine neurons. Science 221:1054-1057

Wiley JL, Compton AD, Porter JH (1993): Effects of four antipsychotics on punished responding in rats. Pharmacol Biochem Behav 45:263-267

Worms P, Lloyd KG (1979): Predictability and specificity of behavioral screening tests for neuroleptics. Pharmacol Ther 5:445-450 